УДК 373.3.091.313:37.014.3

DOI https://doi.org/10.32782/apv/2021.5.19

\title{
Тетяна ФІЛІмОНОВА
}

кандидат педагогічних наук, доцент кафедри початкової освіти, Миколаївський національний університет імені В. О. Сухомлинського, вул. Нікольська, 24, м. Миколаїв, Украӥна, 54000

ORCID: 0000-0002-6722-6333

Бібліографічний опис статті: Філімонова, Т. (2021). Формування пізнавального інтересу молодших школярів на інтегрованих уроках в умовах концепції НУШ. Acta Paedagogica Volynienses, 5, 124-130, doi: https://doi.org/10.32782/apv/2021.5.19

\section{ФОРМУВАННЯ ПІЗНАВАЛЬНОГО ІНТЕРЕСУ МОЛОДШИХ ШКОЛЯРІВ НА ІНТЕГРОВАНИХ УРОКАХ В УМОВАХ КОНЦЕПЦІЇ НУШ}

На сучасному етапі реформування освіти одне з головних завдань - створення необхідних умов для повноцінного розвитку і самореалізації кожного громадянина України. Запорукою ефективності навчальної діяльності й процесу учіння молодших школярів є результативність пізнавальної діяльності, від якої залежить цілеспрямованість розумової активності, розвиток інтелектуальних здібностей та природжених задатків учнів.

У статті розкрита проблема формування пізнавального інтересу учнів початкових класів на інтегрованих уроках в умовах концепиії Нової української школи. Розглянуто поняття «інтерес», «пізнавальний інтерес», «інтеграиія».

Зазначено, щзо головне в системі роботи для розвитку пізнавального інтересу молодших школярів полягає в тому, щзо процес навчання повинен бути напруженим та захоплюючим, а стиль спілкування - м'яким та доброзичливим. Необхідною передумовою успішного навчання є створення атмосфери радості, допитливості та інтересу до навчального процесу. Розвитку пізнавальних інтересів учнів початкових класів у процесі навчання необхідно забезпечити правильний баланс репродуктивної та продуктивної діяльності, вміле включення емочійного матеріалу та постійне стимулювання учнів на всіх рівнях пізнавальної активності.

Як висновок, у статті наголошується, що одним з ефективних способів активізації пізнавальної діяльності учнів початкової школи є інтегроване навчання. В умовах Нової української школи інтегроване навчання розглядається крізь призму цілісного світогляду (велика ідея) і не поділяється на окремі дисципліни.

Таким чином, інтегроване навчання допомагає як учителям, так $і$ учням. Учитель бачить свій предмет по-новому, чіткіше розуміє його взаємозв'язок з іншими науками та починає поєднувати можливості різних дисцииплін для створення цілісних уявлень учнів про світ, суспільство, науку та мистецтво. Тим часом учні широко розвиваються, набувають нових иілісних знань про світ, по-новому сприймають реальність $і$ з иіккавістю ходять до школи.

Ключові слова: інтерес, пізнавальний інтерес, інтеграція, Нова украӥнська школа.

\section{Tetiana FILIMONOVA}

Ph.D. in Pedagogy, Associate Professor at the Department of Primary Education of V. O. Sukhomlynskyi National University of Mykolaiv, Nikolskaya Str., 24, Mykolaiv, Ukraine, 54000

ORCID: 0000-0002-6722-6333

To cite this article: Filimonova, T. (2021). Formuvannia piznavalnoho interesu molodshykh shkoliariv na intehrovanykh urokakh $\mathrm{v}$ umovakh kontseptsii NUSH [Formation of cognitive interest of junior schoolchildren in integrated lessons in the concept of the New Ukrainian school]. Acta Paedagogica Volynienses, 5, 124-130, doi: https://doi.org/10.32782/apv/2021.5.19

\section{FORMATION OF COGNITIVE INTEREST OF JUNIOR SCHOOLCHILDREN IN INTEGRATED LESSONS IN CONDITIONS CONCEPTS OF THE NEW UKRAINIAN SCHOOL}

At the presentstage of education reform, one of the main tasks is to create the necessary conditions for the full development and self-realization of every citizen of Ukraine. The key to the effectiveness of educational activities and the learning process of junior high school students is the effectiveness of cognitive activity, which depends on the purposefulness of mental activity, the development of intellectual abilities and innate talents of students. 
The article reveals the problem of formation of cognitive interest of primary school students in integrated lessons in the concept of the New Ukrainian school. The concepts of "interest", "cognitive interest", "integration" are considered.

It is noted that the main thing in the system of work for the development of cognitive interest of younger students is that the learning process should be intense and exciting, and the style of communication - soft and friendly. A necessary prerequisite for successful learning is to create an atmosphere of joy, curiosity and interest in the learning process. The development of cognitive interests of primary school students in the learning process is necessary to ensure the right balance of reproductive and productive activities, skillful inclusion of emotional material and constant stimulation of students at all levels of cognitive activity.

In conclusion, the article emphasizes that one of the effective ways to enhance the cognitive activity of primary school students is integrated learning. In the New Ukrainian school, integrated learning is considered through the prism of a holistic worldview (a great idea) and is not divided into separate disciplines.

Thus, integrated learning helps both teachers and students. The teacher sees his subject in a new way, understands its relationship with other sciences more clearly and begins to combine the possibilities of different disciplines to create a holistic view of students about the world, society, science and a rt. Meanwhile, students develop widely, acquire new holistic knowledge about the world, perceive reality in a new way and go to school with interest.

Key words: interest, cognitive interest, integration, New Ukrainian school.

Актуальність проблеми. Активізація пізнавальних інтересів у здобувачів початкової освіти $є$ однією з актуальних проблем сучасності. Швидкий розвиток освітнього процесу, хвиля інноваційних перетворень, що охопила світ, ініціюють всебічний розвиток творчо обдарованої, мобільної та конкурентоспроможної особистості в системі освіти, що у свою чергу вимагає активізації пізнавальної діяльності дітей початкової школи.

Цілеспрямована пізнавальна діяльність лише починає формуватися в учнів початкових класів. Тому важливо, щоб учитель міг розвивати цілеспрямовану пізнавальну діяльність і не допускати цього процесу до спонтанного формування.

Як правило, у класах початкової школи змінюються пріоритети цілей навчання: на перший план виходять пізнавальна функція, культ діяльності, самостійність та нестандартизоване мислення, що забезпечує розвиток інтелекту дитини. Основна роль учителя полягає в тому, щоб кожен урок стимулював розвиток та активізацію пізнавальних інтересів учнів.

В умовах Нової української школи (НУШ) інтегроване навчання розглядається крізь призму цілісного світогляду (велика ідея) і не поділяється на окремі дисципліни. Це навчання на основі інтегрованого підходу. Здобувачі освіти потребують відкритих можливостей для інтеграції знань та навичок, що покращують пізнавальну діяльність. Інтеграція може вирішити багато проблем у системі освіти. Психологи та педагоги постійно шукають оптимальні шляхи вдосконалення пізнавальної діяльності. Комплексне навчання $\epsilon$ ефективним способом активізації пізнавальної діяльності у дітей молодшого шкільного віку.
Проте система інтегрованого навчання все ще недостатньо розвинена і тому не досить чітко сприймається багатьма викладачами, а це зумовлює актуальність нашого дослідження.

Аналіз останніх досліджень і публікацій. В Україні встановлено ряд наукових напрямів вивчення теоретичних основ інтеграції. Найважливішими є: напрям методологічного обгрунтування інтеграційних проблем (С. Гончаренко, Ю. Мальований, О. Сергєєв); визначення структури інтегрованих знань (Т. Усатенко); дослідження системних аспектів інтеграції (О. Джулик, Є. Яворський); проблеми інтегративних процесів у освіті (I. Богданова); розроблення шляхів реалізації інтеграції в освітній процес (Л. Вичорова, Т. Горзій, О. Проказа, Є. Романенко); інтеграція засобів управління в модульному навчанні (Л. Джулай); інтеграція теоретичного та продуктивного аспектів навчання (Т. Якимович); імовірнісні та статистичні аспекти інтеграції (В. Якиляшек); інтеграція у вищу освіту (Ю. Жидецький); зв'язки між інтеграцією та диференціацією (В. Моргун); психологічні аспекти інтеграції (Т. Яценко); формування системи знань - дидактична інтегралогія (І. Козловська).

В Україні встановлено ряд наукових напрямів вивчення теоретичних основ інтеграції. Найважливішими 6 : напрям методологічного обгрунтування інтеграційних проблем (С. Гончаренко, Ю. Мальований, О. Сергєєв); напрям на визначення структури інтегрованих знань (Т. Усатенко); дослідження системних аспектів інтеграції(О. Джулик, Є. Яворський); проблеми інтегративних процесів в освіті (І. Богданова); розроблення шляхів реалізації інтеграції в освітній процес (Л. Вичорова, Т. Горзій, О. Проказа, 
С. Романенко); інтеграція засобів управління в модульному навчанні (Л. Джулай); інтеграція теоретичного та продуктивного аспектів навчання (Т. Якимович); імовірнісні та статистичні аспекти інтеграції (В. Якиляшек); Інтеграція у вищу освіту (Ю. Жидецький); зв'язки між інтеграцією та диференціацією (В. Моргун); психологічні аспекти інтеграції (Т. Яценко); формування системи знань - дидактична інтегралогія (І. Козловська).

Мета дослідження - теоретичне обгрунтування інтегрованого навчання на формування пізнавального інтересу учнів початкової школи.

Виклад основного матеріалу дослідження. Одним 3 основних показників виховання, формування та розвитку особистості здобувача початкової освіти є пізнавальний інтерес, рівень розвитку якого багато в чому визначає продуктивність навчального процесу. Важливість розвитку пізнавального інтересу учнів початкової школи до сучасних умов навчання не викликає сумнівів. Однак питання про те, як можна досягти найбільшого ефекту від його розвитку, все ще залишається відкритим. Спираючись на психолого-педагогічні дослідження в даній галузі, ми вважаємо, що вирішення цієї проблеми неможливе без теоретичного обгрунтування поняття «пізнавальний інтерес», в якому ми спираємось на теоретичні засади психології та педагогіки, що розкривають сутність та основні особливості інтересу, а також його значення в розвитку особистості.

Поняття «інтерес» дослівно 3 латинської мови «interest» означає «важливо, має значення». Якщо ж звернутися до українського освітнього словника Семена Гончаренка, то ми знаходимо трактування «інтересу» як справжньої причини людської дії, бажання пізнати об'єкт чи явище, оволодіти певною діяльністю (Нікітіна, 2011).

Аналіз літератури з даної проблеми дозволяє визначити поняття «інтерес» як неоднозначне. Його зміст пов'язаний 3 характеристиками соціальних груп різних спільнот (суспільні інтереси) та 3 характеристиками особистості (особисті інтереси).

Психологи стверджують, що пізнавальний інтерес $\epsilon$ найважливішою частиною загального явища інтересу. Вони визначають пізнавальний інтерес як найважливішу властивість особистості: пізнавати світ не тільки заради біологічної та соціальної орієнтації в дійсності, а й прагнення проникнути в його різноманітність, відобразити у свідомості основні аспекти, причинно-наслідкові зв'язки, закономірності, суперечливості. Таким чином, у своїх дослідженнях Г. Щукін визначає своєрідність пізнавального інтересу у складному ставленні до світу предметів, явищ, під час їх детального вивчення, в постійному та самостійному засвоєнні знань у галузі інтересів, в активному та діяльному придбані необхідних для цього способів, щоб наполегливо долати труднощі (Назарець, 2009). Щодо сутності цього явища дослідник розуміс пізнавальний інтерес як «вибіркову спрямованість особистості, яка спрямована на сферу знань, іiї об'єктивну сторону та процес засвоєння знань. Це стабільне утворення, яке в ході захоплюючих дій більше не потребує зовнішньої стимуляції і стає самопідкріплюючим». Г. Щукіна зазначає, що цей пізнавальний інтерес не $є$ процесуальним, а $є$ вираженням інтересу до реальних продуктивних знань, що призводить до чогось нового в розвитку здобувача освіти в цілому (М'ясоїд, 2004).

Якщо ми звернемося до дослідження Н. Морозової, то помітимо дещо іншу точку зору: пізнавальні інтереси спрямовані на процес педагогічного пізнання та його результати. Вчена розглядає інтерес як «емоційно-пізнавальне ставлення (яке є результатом емоційно-когнітивних переживань) до суб'єкта або безпосередньо мотивованої діяльності, ставлення, яке за сприятливих умов переходить в емоційно-когнітивну спрямованість особистості» (Ільченко, 2002).

Аналіз психологічних досліджень явищ пізнавального інтересу дозволяє встановити, що В. Бондаревський, В. Мухіна, С. Рубінштейн характеризують пізнавальний інтерес як: вибіркову спрямованість психічних процесів людини на предмети та явища світу; тенденцію, прагнення, потребу людини займатися саме даною галуззю явищ, діяльністю, що приносить радість; особливі, вибірково наповнені, активні думки, жваві емоції, довільні починання щодо навколишнього світу, його об'єктів, явищ, процесів (Буна, 1997).

В. Сластенін розглядає пізнавальний інтерес як внутрішню рушійну силу навчання, яка виявляється в цілеспрямованому стані здобувача освіти на основі знань, умінь та досвіду творчої діяльності, що характеризується потре- 
бою в знаннях і готовністю до активного сприйняття як до діяльності, що приносить задоволення (Мариновська, 2002).

3 точки зору педагогіки інноваційних учителів ми вводимо праці Ш. Амонашвілі, який визначає пізнавальний інтерес як форму індивідуальних починань, як напрям самостійного пошуку, розуміння таємниць, вільного обговорення проблеми та вирішення складних проблем, утвердження власної думки (Ангеліс, 2007). Здатність організовувати процес навчання та виховання молодших школярів 3 акцентом на пізнавальні інтереси - головна основа досвіду Ш. Амонашвілі. «Радість, пристрасть - емоції, які роблять пізнавальну діяльність сенсом життя дитини», - каже вчитель, вважаючи, що «краще, якщо учень вчиться не заради оцінок, а заради самих знань, заради успіху в пізнанні» (Ангеліс, 2007).

Важливо зазначити, що пізнавальний інтерес, який є важливою складовою частиною пізнавальної діяльності, активно впливає на формування різноманітних відносин: особливе ставлення до певної галузі науки, пізнавальна діяльність, участь у ній, спілкування і соціальна взаємодія зі співучасниками пізнання, формується світорозуміння та світосприйняття.

Молодший шкільний вік вважається початком формування мотивації до навчання, коли у дітей формується «внутрішня позиція учня», що виражається в бажанні піти до школи, долучитися до нової діяльності - навчитися приймати нову соціальну роль серед своїх однолітків. Молодший школяр перебуває в новому для нього середовищі - він бере участь у соціально значущих навчальних заходах, результати яких близькі дорослі оцінюють як високі чи низькі. Розвиток його особистості протягом цього часу безпосередньо залежить від успішності дитини та іiі оцінки як хорошого чи поганого учня. У сфері пізнавальних інтересів можна спостерігати чіткі відмінності серед молодших школярів. Глибокий інтерес до вивчення будь-якого предмета в початковій школі буває рідко, він, як правило, поєднується 3 раннім розробленням спеціальних навичок.

Особливості формування пізнавального інтересу до змісту навчальної діяльності та здобуття знань полягають, на нашу думку, в тому, що це пов' язано $з$ досвідом учня, щоб відчувати задоволення від його успішності (Варій, 2007).
Розглянемо динаміку інтересів молодших школярів. У перші кілька років навчання всі інтереси учня початкової школи розвиваються дуже чітко, особливо пізнавальний інтерес, який виявляється в жадібному прагненні до більшого навчання, в інтелектуальній цікавості. Спочатку існують інтереси до окремих фактів, ізольованих явищ (1-2 класи), потім - інтереси, пов'язані з розкриттям причин, закономірностей, взаємозв'язків та взаємозалежностей між явищами. Першокласники та другокласники кажуть: «Що це?», а якщо їм цікаво, типовими питаннями в старшому віці стають «Чому?» і «Як?».

$\mathrm{У}$ міру розвитку навичок читання розвивається інтерес до читання певної літератури, а хлопчики швидко розвивають інтерес до техніки. Уже з 3-го класу навчальні інтереси починають диференціюватися.

Якщо порівняти пізнавальний інтерес і творчу активність, то можна побачити, що це складні багатогранні явища, які можна розглядати 3 двох боків. По-перше, вони виступають як інструмент навчання, як зовнішній стимул для проблеми допитливості. По-друге, ці поняття $\epsilon$ найціннішим мотивом навчальної діяльності учня (Мартиновець, 2021). Але щоб формування мотивів було недостатнім, вони повинні бути адаптовані до потреб особистості. Тому ми можемо розрізняти внутрішні та зовнішні прояви пізнавального інтересу, а отже, умови, що впливають на їх формування, також можна поділити на внутрішні та зовнішні.

У зв'язку з вищесказаним слід зазначити, що під час формування пізнавального інтересу молодших школярів у процесі виконання різних завдань важливо враховувати як внутрішній, так і зовнішній аспекти. Однак учитель не може повною мірою вплинути на мотиви та потреби особистості учня, тому необхідно зосередитись на навчальних ресурсах і враховувати зовнішні умови.

Отже, продуманий, добре підібраний навчальний матеріал, який буде новим і невідомим, який стимулюватиме уяву учнів, буде вражати їх, який обов'язково включатиме нові досягнення в науці, дослідженнях і відкриттях, буде найбільш важливою ланкою та засобом зацікавлення до навчання. Тому ми можемо зробити висновок, що головне в системі роботи для розвитку пізнавального інтересу молодших 
школярів полягає в тому, що процес навчання повинен бути напруженим та захоплюючим, а стиль спілкування - м'яким і доброзичливим. Необхідною передумовою успішного навчання $\epsilon$ створення атмосфери радості, допитливості та інтересу до навчального процесу.

Серед характерних рис пізнавального інтересу дітей молодшого шкільного віку для нас виявляється така, як ефективність, що виражається в активній діяльності дитини, спрямованій на пізнання предметів та явищ соціальної реальності, труднощів та сили волі для подолання мети.

Тому можна стверджувати, що для розвитку пізнавальних інтересів учнів початкових класів у процесі навчання необхідно забезпечити правильний баланс репродуктивної та продуктивної діяльності, вміле включення емоційного матеріалу та постійне стимулювання учнів на всіх рівнях пізнавальної активності:

1. Пізнавальний інтерес розпізнається швидше за інші мотиви. «Цікаво» та «нецікаво» - основні критерії оцінки уроку.

2. Пізнавальний інтерес краще спостерігається. Його легше виявити, спричинити, відповідно, їм легше управляти.

3. Пізнавальний інтерес як мотив особистості менш ситуативно задіяний, ніж інтерес як інструмент навчання.

4. Пізнавальний інтерес - це ланка в мотиваційній системі, а не відокремлена від мотивів, якими одночасно керує учень. Це пов'язано з мотивами обов'язку, відповідальності, потреби в самореалізації, соціальними та колективними мотивами тощо. Це потрібно враховувати у формуванні пізнавального інтересу, оскільки зв'язок мотивів збагачує особистість, а інтерес до знань на психологічній основі позитивно впливає на інші мотиви.

Другою важливою вимогою до формування інтересу є наявність чогось нового як у змісті навчального матеріалу, так і в підході до його врахування. Неможливо повторити відомі істини на одному пізнавальному рівні. Для глибшого розуміння матеріалу необхідно розширити кругозір знань учнів.

Третьою передумовою сприяння інтересу молодшого шкільного віку є емоційна привабливість навчання. Учитель повинен прагнути, щоб знання, отримані на уроці, викликали емоційний відгук учнів та активізували їхні моральні, інтелектуальні та естетичні почуття.
Четвертою умовою для тренування інтересу $є$ наявність оптимальної системи тренування творчих вправ та пізнавальних завдань для відповідної «частини» навчального матеріалу програми.

Інтеграція - одна 3 найважливіших галузей змін у сучасній школі сьогодні та усунення суперечностей між постійно зростаючим обсягом знань та здатністю їх опановувати. Інтеграція може вирішити багато проблем у системі освіти. Звичайно, система інтегрованого навчання все ще недостатньо розвинена і тому не досить чітко сприймається багатьма вчителями. Повне теоретичне обгрунтування та впровадження в практику в класі - це питання майбутнього. Але навіть сьогодні очевидно, що інтегроване навчання, як ніяке інше, створює нові умови для вчителів і учнів та $є$ ефективною моделлю для активізації пізнавальної діяльності та розвитку прийомів навчання. Сучасна педагогіка розглядає інтеграцію як один із найважливіших дидактичних принципів.

В умовах Нової української школи інтегроване навчання розглядається крізь призму цілісного світогляду (велика ідея) і не поділяється на окремі дисципліни, це навчання на основі інтегрованого підходу.

Межі перетинаються, коли вчителі заохочують учнів створювати зв'язки між дисциплінами та спиратися на знання і вміння з різних предметних областей. Учні потребують відкритих можливостей для інтеграції знань та навичок з різних дисциплін та критичної оцінки взаємодії всіх цих частин.

Інтегровані уроки використовуються для ефективної інтеграції в навчальний процес. Такі уроки поєднують блоки знань із різних предметів, тем навколо проблеми. На думку Л. Куліченко, інтегрований урок - це урок, який проводиться з метою розкриття загальних законів, ідей, теорій, відображених у різних науках і відповідних їм предметах (Куліченко, 2012).

Мета викладання на інтегрованій основі створити умови для всебічного розгляду певного предмета, поняття, явища, формування системної мови, уяви та розвитку позитивного емоційного ставлення до сприйняття (Мариновська, 2002).

Готуючись до уроку, вчителіповинні ретельно продумати зміст діяльності уроку та використовувати різні методи їх презентації, щоб принести радість першого відкриття кожному учню. 
Це сильний стимул активізувати не лише мислення, а й усю особистість (Мариновська, 2004).

Висновки i перспективи подальших досліджень. Підсумовуючи, можна виділити особливості формування пізнавального інтересу в молодших школярів, а саме когнітивний інтерес до навчального процесу, з одного боку, як мотив навчання, а 3 іншого - як умову успішного навчання.

Одним 3 ефективних способів активізації пізнавальної діяльності учнів початкової школи $\epsilon$ інтегроване навчання. В умовах Нової української школи інтегроване навчання розгляда- ється крізь призму цілісного світогляду (велика ідея) і не поділяється на окремі дисципліни. Це навчання на основі інтегрованого підходу.

Таким чином, інтегроване навчання допомагає як учителям, так і учням. Учитель бачить свій предмет по-новому, чіткіше розуміс його взаємозв'язок 3 іншими науками та починає поєднувати можливості різних дисциплін для створення цілісних уявлень учнів про світ, суспільство, науку і мистецтво. Тим часом учні розвиваються, набувають нових цілісних знань про світ, по-новому сприймають реальність і $з$ цікавістю ходять до школи.

\section{ЛITЕРАТУРА:}

1. Ангеліс К. Формування критичного мислення особистості в аспекті розробки концептуальної моделі розвитку особистісної. Психологічна безпека та адаптаиія особистості : матер. Міжнар. наук.-практ. конф. (Дніпропетровськ, 7-8 лист. 2007 р.) / за ред. О. Шевякова. Дніпропетровськ, 2007. С. 69-76.

2. Буна Н. Головко 3. Довідник: Українська мова в схемах і таблицях : посібник для учнів 1-4 класів. Тернопіль : Богдан, 1997. 32 c.

3. Варій М. Загальна психологія : навчальний посібник. 2-ге вид., випр. і доп. Київ : Центр учбової літератури, 2007. 968 c.

4. Ільченко В. Інтеграція змісту освіти та сучасні проблеми загальноосвітньої школи. Імідж сучасного педагога. 2002. № 2 (21). С. 14-17.

5. Куліченко Л. Інтегровані уроки як один із засобів підвищення активності учнів на уроках. Таврійський вісник освіти. 2012. № 1. С. 250-254.

6. Мариновська О. Інтегральна педагогічна технологія предметів суспільно-гуманітарного циклу. Обрії : наук.педагогічний журн. 2004. № 1. С. 7-12.

7. Мариновська О. Інтегральна технологія навчання: від теорії до практики. Початкова освіта. 2011. № 32 (608). С. 3-5.

8. Мариновська О. Моделювання навчальних занять на інтегрованій основі : метод. посіб. / за ред. О. Мариновської. Івано-Франківськ : Симфонія-форте, 2002. 136 с.

9. Мартиновець Л. Підвищення ефективності уроку за рахунок інтеграції навчального матеріалу. Новоолександрівка, 2012. $97 \mathrm{c.}$

10. М'ясоїд П. Загальна психологія : навчальний посібник. 3-тє вид., випр. Київ : Вища школа, 2004. 487 с.

11. Назарець Л. Формування пізнавального інтересу учнів. Обдарована дитина. 2009. № 7. С. 59-62.

12. Нікітіна Н. Активізація пізнавальної активності учнів шляхом використання ігрових моментів та цікавих завдань. Початкове навчання та виховання. 2011. № 31. С. 21-31.

\section{REFERENCES:}

1. Anhelis K. Formuvannia krytychnoho myslennia osobystosti v aspekti rozrobky kontseptualnoi modeli rozvytku osobystisnoi [Formation of critical thinking of the personality in the aspect of development of the conceptual model of development of personal]. Psykholohichna bezpeka ta adaptatsiia osobystosti: mater. Mizhnar. nauk.-prakt. konf. (Dnipropetrovsk, 7-8 lyst. 2007 r.) / za red. O. Sheviakova. Dnipropetrovsk, 2007. S. $69-76$ (in Ukrainian).

2. Buna N. Holovko Z. Dovidnyk: Ukrainska mova v skhemakh i tablytsiakh [Handbook: Ukrainian language in diagrams and tables]. Posibnyk dlia uchniv 1-4 klasiv. Ternopil : Bohdan, 1997. 32 s. (in Ukrainian).

3. Varii M. Zahalna psykholohiia [General Psychology]: navchalnyi posibnyk / 2-he vydan., vypr. i dop. Kyiv : Tsentr uchbovoi literatury, 2007. 968 s. (in Ukrainian).

4. Ilchenko V. Intehratsiia zmistu osvity ta suchasni problemy zahalnoosvitnoi shkoly [Integration of educational content and modern problems of secondary school]. Imidzh suchasnoho pedahoha. 2002. № 2 (21). S. 14-17. (in Ukrainian).

5. Kulichenko L. Intehrovani uroky yak odyn iz zasobiv pidvyshchennia aktyvnosti uchniv na urokakh [Integration of educational content and modern problems of secondary school]. Tavriiskyi visnyk osvity. 2012. №1. S. 250-254. (in Ukrainian).

6. Marynovska O. Intehralna pedahohichna tekhnolohiia predmetiv suspilno- humanitarnoho tsyklu [Integral pedagogical technology of subjects of social and humanitarian cycle]. Obrii: nauk.-pedahohichnyi zhurn. 2004. № 1. S. 7-12. (in Ukrainian). 
7. Marynovska O. Intehralna tekhnolohiia navchannia [Integrated learning technology: from theory to practice: vid teorii do praktyky]. Pochatkova osvita. 2011. № 32 (608). S. 3-5. (in Ukrainian).

8. Marynovska O. Modeliuvannia navchalnykh zaniat na intehrovanii osnovi [Simulation of training sessions on an integrated basis]: metod. posib. / za red. O. Marynovskoi. Ivano-Frankivsk : Symfoniia-forte, 2002. 136 s. (in Ukrainian).

9. Martynovets L. Pidvyshchennia efektyvnosti uroku za rakhunok intehratsii navchalnoho materialu [Improving the effectiveness of the lesson through the integration of educational material]. Novooleksandrivka, 2012.97 s. (in Ukrainian).

10. Miasoid P. Zahalna psykholohiia [General Psychology]: navchalnyi posibnyk. 3-tie vyd., vypr. Kyiv : Vyshcha shkola, 2004. 487 s. (in Ukrainian).

11. Nazarets L. Formuvannia piznavalnoho interesu uchniv [Formation of cognitive interest of students]. Obdarovana dytyna. 2009. №7. S. 59-62. (in Ukrainian).

12. Nikitina N. Aktyvizatsiia piznavalnoi aktyvnosti uchniv shliakhom vykorystannia ihrovykh momentiv ta tsikavykh zavdan [Activation of students' cognitive activity through the use of game moments and interesting tasks]. Pochatkove navchannia ta vykhovannia. 2011. № 31. S. 21-31. (in Ukrainian). 